\title{
The Environmental Perception in Indonesia: Preliminary Findings
}

\author{
Husnul Khitam \\ Department of Sociology, Syarif Hidayatullah State Islamic University Jakarta \\ husnul.khitam@uinjkt.ac.id
}

\begin{abstract}
Environmental issue has risen in the last few years and affecting many sectors. More fundamentally, it influences the development of theeconomy and also the future of social life. Scholars debate focuses on the macro level such as the effect of democracy or any political regime on environmental degradation [1] and also the relations of corruption, democracy, and environmental degradation.[2]The micro level such as people perception on theenvironment in the worldwidealso become subject of discussion[3]. Whatabout Indonesia? Since the Reformation era, Indonesian people have expressed their thought on social, political and religious issues but rarely on environmental issues. This research is an exertion to dismantle the perception of theenvironment in Indonesia and it's sociological implication by using data from World Values Survey wave 5 .
\end{abstract}

Keywords - the environment, perception, Indonesia, democracy

\section{BACKGROUND}

Environmental issue has risen in the last few years and has become public attention, ranging from state to groups of people with avariedbackground such as social activist, religious organizations or political elites. This cannot be detached from the emergence of environmental problems which caused by multiple factors that directly correlated to human behaviors, geographical conditions and other factors.

Economic development in Asia has confronted by severe environmental problems which might collide the future of the world [4]. In a report, there were four main environmental problems such as poor water management, air pollution, deforestation or illegal logging, land degradation and climate change.

Awareness of the effect of theenvironmenton human nowadays is raising because of the development of human consciousness on environmental degradation which caused by themselves. Factors that affect this degradation have assumed based only on thenatural change at first,but thenhas shifted radically to theanthropocentric point of view which judge that human is the leading cause of environmental degradation. Human ego as the ultimate being and fine creature compare to others is the primary cause of this problems. This statement tends to exaggerate human capacity and conclude that they have the power to put in order of any other creatures.

Anthony Giddens, a prominent sociologist, said that the environmental conditions such as the raising of temperature to 46-Celsius degree in several countries, massive dryness and climate anomaly that happened around the world were caused by human interference and the development of global industry which broughtmassive destruction to their ownsurroundinghabitat[5].

Resosudarmo mentions that based on research conducted by World Health Organization, the level of air pollution in 20 cities was so bad. At least one type of an air pollution in those cities was exceeding the WHO air pollution threshold. Another research has estimated that around 600 million citizens live in a high level of thesulfur dioxide polluted city, and around 1.25 billion people live in an extremely high level of thedustpollutedcity. Furthermore, the high level of air contamination considerably as the primary cause of disease in society [6].

Ostro in Resosudarmo (1994) said that many fatal cases hadbeen found in Jakarta, a city with around 9 million inhabitants in 1990. At that time, there were 1,558 people died at early aged, 39 million suffered sore throat, 555 thousandsuffered asthma, 12 thousandhad bronchitis, and 125 thousand children also had a sore throat because of the high level of air pollution in the city [6].Therefore, based on those problems, we tried to portray how is the picture of environmental perception in Indonesia. We propose a question on how Indonesian general perception on theenvironment and is the perception vary in regards to gender and age group?

\section{PERCEPTION TOWARDS ENVIRONMENT}

Before the further exploration of environmental perception, it is important to understand the meaning ofperception itself. Perception in psychology can be seenwithin two approaches which are conventional or functionalism and ecological approach. In general, conventional approach means as a collection of sensation, whereas ecological approach means that people are 
not creating a meaning individually from what they sawinsteadthe meaning itself has its stimulus and available for any organism [7].

Paul A. Bell etal.said that the forming process of perception begins when a person experiences acontiguity between the sense and environmental objects and end up with a reaction. Furthermore, Bell explains that the initialrelationship between human and its environment is the physical contact between human and objects surrounding the environment. In this process, a perception has defined as a learning process or as a conscious or cognition process[7].

In general, the perception is determined by experiences and experiences is determined by aculture which also includedthe daily habit. Henceforth, regarding the changes of perception, it dividesinto two processes. First, aphysiological change which causes by aphysicalprocess in nerve system. Second, psychological processes[7].

How is the development of the study of environmental perception? Environmental perception is not a brand new issue in social sciences. Several studies tried to look at people perception of theenvironment at thevarious level.

Research using World Values Survey 1990-2001 data shown that conventional point of view that theenvironmental perception is only high in the wealthy countries is incorrect. Preliminary findings from Gallup survey in 24 countries demonstratedthat there was a negative relationship between theaffluence of a countryand on how its people put their attention and perception on theenvironment. This finding also strengthened by the major conclusion that perception and environmental awareness was not related to the level of richness or in more advanced the level of affluence and post-material values [3].

Another study by WWF and LP3ES in 2013 shows people' perception on the environment. The survey was conductedinseven cities in Indonesia. The resultsdemonstrated that several environmental problems were not caused by the geographical and natural factors, but in fact, it was caused by human's behavior, such as extracting and consuming natural resources irresponsibly and doing immoral action like corruption. Thisled to people's distrust of political parties who are related the problems [8].

\section{DEMOCRACY AND ENVIRONMENTAL CONCERN}

Defining democracy in relations with environment is a timeless effort. There were several terms used as an identity of democracy and environment such as environmental democracy [9] which known as a participatory and ecologically rational form of collective decision-making [9].

Various scholars have tried to examine the effect of democracy towards the environment. Some scholars believe that democracyreduces environmental degradation [1], eventhough other scholars seen the positive impact of democracy, it also has the adverseeffect that might cause ecological problems such as deforestation [10].

The debate on this relation also laid on several arguments such as centralism or ecological dictatorship or decentralism or ecological democracy [11]. Eventhough, in some point, democracy is not the ultimate value. It also possible that democracy might clash with other values in theory and practice [11].

The most crucial aspect of environmental concern is how people perceive their surrounding environment starting from their perceptions. Therefore, about democracy, looking for the environmentalmatter of a country is an alternative way toinvestigate the internalizationprocess of democratic norms that can promote the growthpublic participation to produce democratic citizens, and affect the policy processes [12].

MacAndrews (1994),in hisstudy, shows that academic and public attention to the environment recently happened in Indonesia, mainly related to the economic development started from the 1960s. This studyrevealed how the interrelation between politics and the environment, especially how a regime uses an environmental issue and how a contestation within groups and state at the time and after the fall of the New Order[13].

From several studies aforementioned, it was seen that there is an unexplored issue, especially on how environmental perception was constructed in Indonesia. This might resultin a new insight on understanding the environmental problems in Indonesia.

\section{IV.RESEARCH METHODOLOGY}

The primaryaim of this study is to find out the community perception of theenvironment in Indonesia. This research was using positivism paradigm and descriptive-quantitative method with secondary data as the main data source. In social research methods, this kind of study is known as the Secondary Analysis.

This research used World Value Survey Wave 5 data which was collected during 2005 - 2008. During this period of thesurvey, there wasfour countries from Southeast Asia region selected as the sample, Indonesia, Malaysia, Thailand, and 
Vietnam. However, in this paper, I only describe Indonesia as the main analysis.

Regarding the source of data, from hundreds of questions that wereaskedin the survey, only several questions related to this research. There were questions V104 until V113. These questions were related to perception ofenvironment among Indonesian people.

The further step was to do the quantitative data analysis. The data processing was done by using specific software[14]. Several steps were taken, such as anidentificationprocess on the possibility of missing data and also a categorization of the data. Further analysis was also used to identify the validity of the data, and the last step was descriptive statistics, especially frequency distribution as the primary tools for describing the perception of theenvironment.

\section{THE ENVIRONMENTAL PERCEPTIONS IN INDONESIA}

In 1995, there was a survey conducted by Gallup under the title Health of the Planet Survey. This survey came up with unusual findings. The main findingbroke the common assumption that wealth alwayshad a positive relationship with the environmental concern. Research showed that the institutional and economic problems in poor countries might be the cause of environmental degradation [15].

Public perception of theenvironment ismore unexplored than other issues. Most Indonesian scholars put their foci on economy, politics and religious issues, such as a perception of candidacy in political rally or people perception on religious extremism. In 2006, studies conducted by world value survey and explore many aspects of values. The environment is one of the focus of the research.

In general, this research conducted in 10 provinces in Indonesia (Lampung, Jakarta, West Java, Central Java, Yogyakarta, East Java, Banten, West Nusa Tenggara, South Kalimantan and Central Sulawesi) and this gave an insight on how the Indonesian perceive the environment.

By using cartesian point of view, economic growth is seen as the main problem of the nation in preserving the environment. The ecologist has put the development processes as the main factor that caused environmental degradation. This survey showed an inclination to themoderate trend. In general, 28.1 percent respondent said that preserving the environment was their priority eventhough it might deprioritize the economic growth, or at least submerged the growth. This type of thought appeared from the younger generation (30.7\%) which were more adaptive to the issues.

Meanwhile, an intention on environmental preservation had also been arising. 67 percent of respondent said that they would set aside part of their incomes to restrain the destruction of theenvironment. In the meantime, only 25.7 percent expressed their disagreements.The indirect contribution was also part of the people's concern. In this case, the contribution is theincreasein taxes. Eventhough the majority of respondents (54.8 percent) said that they might accept the rise intax to prevent pollution and environmental degradation, 38.2 percent of therespondents expressed their disagreement. This condition might cause complication on how government makes a policy such as the use of mass transportation and therefusal of private vehicle taxes. Who is the responsible actor? For most of the respondents, the leading actor who should take the responsibility was the state or government. Therefore, the majority said their agreement that government is the actor in charge of reducing pollution without any impact on people's financial aspect.

In the context of problems in theenvironment, people perception can be seen through several aspects. The first elementis of poor water quality. 66.7 percent of respondents affirmed that water condition in Indonesia is poor while only 21.2 percent claimed on the other way. Hundreds of young people convinced that it was a problem and on the contrary, older people felt that it was an ordinary condition.

The second aspect was poor air quality. Most people said that this was a seriousand big problem and (75.3 percent). In more specific detail, both gender and group of ages also agreed that the air quality was very poor. This might be caused by the high pollution whichleads to the climate change. The third aspect was poor sewage and sanitation. In this aspect, people saw that the wastewater and sanitation management was severely managed. Hence, there is a need to find a comprehensive solution (75.5 percent) and only 14.4 percent felt that this problem was not so serious. The fourth aspect was climate change issue which has been causing global warming. The majority of respondents have sufficient knowledge and awareness on this topic. 64.5 percent of respondents said that the climate change was quite severe and need to be tackledwith fullattention.

The fifth aspect was aperception on environmental condition which caused biodiversity loss. Most people believed that this loss should be put in priority (70.5 percent). The similar input can also be seen on the sixth aspect, which was the perception of pollution of river, lakes, and oceans. 
The majority expressed that the pollution is very riskyand might cause massive disease (68 percent).

Therefore, if we see these preliminary findings, Indonesian perception on theenvironmentcan be considered as generally high and positive. All genders and age groups showed the equal level of awareness. Along with researchconducted in Barbados, Thailand, Costa Rica and Cina that revealedamodest difference between male and femal perception on environmental concern[16].

\section{References}

[1] Q. Li and R. Reuveny, "Democracy and Environmental Degradation,” Int. Stud. Q., vol. 50, pp. 935-956, 2006.

[2] L. Pellegrini and R. Gerlagh, "Corruption, Democracy, and Environmental Policy: An Empirical Contribution to the Debate," $J$. Environ. Dev., vol. 15, pp. 332-354, 2006.

[3] R. E. Dunlap and R. York, “The Globalization of Environmental Concern and The Limits of The Postmaterialist Values Explanation: Evidence from Four Multinational Surveys,” Sociol. Q., vol. 49, no. 3, pp. 529-563, 2008.

[4] S. Howes and P. Wyrwoll, "Asia's Wicked Environmental Problems,” 348.

[5] A. Giddens, Runaway World: Bagaimana Globalisasi Merombak Kehidupan Kita [Runaway World: How Globalization Reorganize Our Life]. Jakarta: PT. Gramedia Pustaka Utama, 2003.

[6] B. P. Resosudarmo, "Kebijakan di Bidang Lingkungan Hidup, Pertumbuhan Ekonomi dan Distribusi Pendapatan [The Policy in Environment, Economic Growth and Income Distribution]."

[7] S. W. Sarwono, Psikologi Lingkungan [Environmental Psychology]. Jakarta: Grasindo, 1992.

[8] WWF and LP3ES, "Ringkasan Survey Perspesi Masyarakat Terhadap Isu Lingkungan dan Preferensi Partai Politik [Summary of Survey of Community Perception on Environmental Issues and Political Party Preference],” 2013.

[9] M. Mason, Environmental Democracy. London: Earthscan Publications Ltd, 1999.

[10] M. Buitenzorgy and A. P. J. Mol, “Does Democracy Lead to a Better Environment? Deforestation and the Democratic Transition Peak," Environ. Resour. Econ., vol. 48, no. 1, pp. 59-70, 2011.

[11] J. Radcliffe, Green Politics: Dictatorship or Democracy? New York: Palgrave, 2002.

[12] S. T. Marquart-pyatt, "A Comparative Analysis of Environmental Concern,” The Ohio State University, 2004.

[13] C. MacAndrews, "Politics of the Environment in Indonesia,” Asian Surv., vol. 34, no. 4, pp. 369-380, 1994.

[14] A. Bryman, Social Research Methods. New York: Oxford University Press, 2012.

[15] R. E. Dunlap, "Environmental Concerns and the Third World,” Science, vol. 268, no. 5214, pp. 1114-1115, 1995.

[16] J. H. Momsen, "Gender differences in environmental concern and perception," $J$. Geog., vol. 99, no. 2, pp. 47-56, 2000. 